\title{
1 Decision Making by Specialist Luxury Travel Agents
}

2

\section{Abstract}

4

5 We report an ethnographic study of specialist travel agents in luxury wildlife tourism.

7

8

Agents consider 30 factors in 5 groups, related to client, destination, attraction, operator and agent. They consider the groups in sequence rapidly and intuitively. They are driven by a powerful regard for the high expectations of wealthy clients, and a sense of responsibility to the clients, but they assume authority over the decision. They rely on personal experience with each particular place and tourism product, and sell only what they know. One of their skills is to project themselves into the client's perspective so as to imagine a trip in great detail. This process contrasts strongly with the explicit deterministic approach used by retail travel agents in high-volume lower-priced subsectors, where earnings are driven by commission and incentive structures. For high-end agents, establishing long term relationships of mutual trust with individual clients and tour operators is paramount.

Keywords: power, expectations, empathy, experience, expertise, marketing, tacit, wildlife 


\section{Introduction}

Travel agents are a key component of the tourism industry (Baloglu \& Mangaloglu, 2001; Klenosky \& Gitelson, 1998; Lovelock, 2008; McKercher, Packer, Yau, \& Lam, 2003). As the technical logistics of travel purchases have changed, agents are no longer ubiquitous intermediaries in every transaction (Cheyne, Downes, \& Legg, 2006; Kracht \& Wang, 2010). Individual tourists can now identify options and make purchases online, especially for simpler and less expensive components (Abou-Shouk, Lim, \& Megicks, 2013; Berne, GarciaGonzalez, \& Mugica, 2012; Buhalis \& Law, 2008;). This has led to widespread disintermediation in high-volume low-price tourism distribution chains (Huang, Huang \& Chen, 2004; Novak \& Schwabe, 2009; Song, Van der Veen, Li \& Chen, 2012).

In high-end specialised sectors, however, travel agents have become information brokers, using their expertise to find lower prices or better experiences, or to research, plan, package and purchase customised itineraries for their clients (Buckley, 2014; Dolnicar \& Laesser, 2007; Hudson, Snaith, Miller, \& Hudson, 2001; Lawton \& Weaver, 2009). Cash-rich, timepoor clients prefer to delegate their holiday choices to expert travel agents, to a greater degree than cash-poor, time-rich travellers (Buckley, 2014; Cheong \& Miller, 2000; Park \& Jang, 2013). In these higher-price, lower-volume specialised subsectors of tourism, therefore, travel agent decisions exert substantial influence on the financial success of individual tourism businesses and entire tourism destinations. The factors which these agents consider, and the processes by which they balance these factors to reach their final decisions, are therefore of considerable interest from both practical and theoretical perspectives (Lam \& Hsu, 2006).

Decision processes have been studied intensively for individual tourists (Bargeman \& Van der Poel, 2006; Decrop \& Snelders, 2005; Hsu, Tsai \& Wu, 2009; Jeng \& Fesenmeier, 2002; Moore, Smallman, Wilson, \& Simmons, 2012; Sirakaya \& Woodside, 2005). They have also been studied for travel agents serving high-volume low-price sectors (Klenosky \& Gitelson, 1998; Lawton \& Page, 1997; Michie \& Sullivan, 1990), where agent decisions are driven principally by sales commissions (Davies \& Downward, 2007; Gustafson, 2012; Huang, Huang, \& Chen, 2004). Paradoxically, however, decision processes have been much less studied for specialist agents in high-end tourism. 
Decision processes of high-end travel agents are difficult to dissect, because they are based on confidential information and tacit expertise. To analyse these processes, naturalistic as well as rationalist approaches are required. Rationalist models assume that all relevant information is available in a form where different considerations can be aggregated and balanced against each other in a deterministic manner (Thunholm, 2004; Saaty, 2008). Such models are applicable, for example, to low-end travel agent decisions based largely on commission structures. Naturalistic models recognise that people often make decisions based on incomplete information, and may be influenced by context-dependent peripheral and emotional factors (Gore, Banks, Millward, \& Kyriakidou, 2006).

Here, therefore we analyse decision processes for high-end travel agents in one specialist sector, namely luxury wildlife lodges and safaris in sub-Saharan Africa. High-end wildlife tourism operators worldwide rely heavily on small sets of specialised agents, in different countries of origin, to send them a steady supply of clients. Our approach and results are applicable to most high-end tourism subsectors.

\section{Methods}

Since luxury wildlife tourism is a large, multilingual sector, we focused on a restricted and coherent subgroup with a single language and locality, namely Francophone Switzerland. We use an ethnographic approach, with a qualitative insider methodology. This was possible since the principal author is herself a specialist high-end wildlife tourism travel agent based in the Geneva region, routinely booking wealthy French-speaking Swiss clients on wildlifewatching holidays in sub-Saharan Africa. She has held that position for over a decade. She left it specifically to conduct this research, and has now returned to it. That is, she is herself a long-term member of the group studied here, subject to the same professional pressures and standards.

This provides access to ethnographic detail and insights not otherwise available, including the opportunity to interview other such agents repeatedly and to discuss findings iteratively from an insider perspective. Determining reliably how people make particular decisions is a difficult process. Individuals do not always identify, e.g.: what those decisions involve; what factors they consider and why; how and why they balance and prioritise such factors; and 
how explicit logical and utilitarian considerations may interact or be influenced by implicit emotional or affective factors. A long-term ethnographic approach is the most reliable method to understand how decisions are made under such circumstances.

During this study in 2013-2015, there were precisely 15 specialist French-speaking Swiss travel agents booking luxury wildlife tours and lodges in sub-Saharan Africa. This study included all 15 of these agents. They were 30-60 years old, eight females and seven males. All were expert in luxury and wildlife tourism and had many years' experience in their current positions. [Author 2] is a $16^{\text {th }}$ member of this cohort. Her own experience aided in unravelling intangible factors and building the model of the decision process.

Semi-structured interviews with each of these 15 agents were conducted in French. To maximise the depth and reliability of the information obtained, each research subject was interviewed several times, over an extended period. Initial conversations were open and unstructured, leading gradually to questions about clientele, preferred suppliers, booking procedures, and decision factors and processes. Insider expertise and tacit knowledge were used to assist in obtaining critical information from each interviewee.

Interviews were conducted face-to-face or via Skype ${ }^{\circledR}$. Each individual interview took 1-2 hours. No inducements were offered, and interviewees were informed of the purpose of the research. Interviews were recorded, with permission. The recordings were analysed and coded manually, by listening to them repeatedly in French. This approach was preferred to transcribing and electronic coding, in order to retain inflexions and implications in spoken language, regarding potentially sensitive information. That is, in many cases interviewees referred implicitly to issues, individuals or firms known to both interviewer and interviewee, but without naming them explicitly, because of concerns over ethical and professional protocols.

Our analysis follows a multi-stage grounded theory approach. First, we used an open basic coding process to identify tangible or extrinsic factors which agents say that they consider in making their decisions. We grouped these factors iteratively into higher-tier constructs or categories, following a standard qualitative deconstruction/reassembly process (Silverman, 2010; Punch, 2014). Second, we used axial coding (Punch, 2014) to identify the internal, 
intrinsic or psychological themes that arise repeatedly when agents described how they combine the extrinsic factors in order to arrive at a decision.

We included a reflexive test of reliability at each stage in the analysis, by presenting each step to the agents interviewed, and discussing it with them in detail. A number of earlier and simpler conceptual models were discarded as a result of this reflexive process, which provides high reliability and confidence in the final model. The major steps comprising the final model match how the agents themselves conceptualise their decisions. The finer-scale details, expressed in the external factors and internal themes, were not apparent to the travel agents themselves prior to this analysis, but were endorsed once the analysis was completed and presented.

\section{Results}

Open coding identified 30 individual external factors in 5 main categories, summarised in Table 1, that are considered sequentially by these specialist travel agents in making their decisions. Axial coding yielded 4 coherent themes, discussed and illustrated below, that drive how agents integrate these tangible external factors to reach their decisions.

The 5 groups of external factors are related respectively to the client, destination, attraction, operator and agent. Client factors include: a specified price range, specific requests, the client's previous experiences, their current expectations, and their relationship with the agent. Agents refer to this first step as "profiling" the client, and refer repeatedly to "the client's profile”. Destination factors include access logistics and infrastructure, health concerns, seasonality, political stability, booking procedures, reliability, and time-efficiency. Agents comment, e.g., that they would prefer to use "one on-ground intermediary per country to gain time"; that they are "used to working with" particular operators and intermediaries because this is "easier for booking procedures"; and since they are "dealing with lots of tasks each day" they will generally "prioritise an operator that makes life easy".

The attraction factors are the attributes of the product on-site, and include the specific location, scenery, quality of the wildlife viewing, activities, service, luxury and exclusivity. The quality of the wildlife viewing includes wildlife density, diversity and proximity, and 
commonly depends on location and season. Exclusivity is strongly sought after by high-end clients. It includes location, design, specialty features, five-star service, and guest-list restrictions. Accurate knowledge of wildlife and exclusivity factors are key aspects of agent expertise, relied on heavily by clients. Agents comment, for example, that "location is a key factor" and they select "areas where wildlife is abundant" and lodges that are "beautiful and exclusive”.

The operator factors include: communication and marketing materials; intermediary suppliers for each operator; the operators' outbound sales representatives; and each operator's specific sites, products and business practices. The agent factors include: the agent's exposure to each operator's products; their professional views of each operator's business practices; their personal relationships with each operator's staff and sales personnel; and their personal desire to provide support for each operator, eg for conservation or community development efforts. They also include: each agent's individual interests or biasses towards particular sites, scenery of wildlife species. For example, agents mention factors such as operators' “work ethics" and their own "favourite products".

In particular, some of the agents referred specifically to conservation projects and practices by particular tourism operators, saying that it was "critical that operators take part in conservation", that they are "very interested in operators' conservation projects", or in one case, that they were " $80 \%$ influenced by conservation in the selection of operators". This applies even though they know that "conservation has a price" and "the top operators are the most expensive". One agent said that they "know about cheetah conservation problems", but others said that they were "not aware of lion conservation issues" and "not aware of leopard conservation issues". One agent considered that they "need to know these things so we can have a competitive advantage”, but another argued that “operators that have an interesting product with conservation aspects but which are located in remote areas need to give us the tools to sell the product and facilitate the logistics”. Agents admitted, however, that they receive "hundreds of newsletters every day" and "do not have time to read all of them", and in consequence, "conservation messages are lost”.

Some of these factors are straightforward, such as client budget, distance, health considerations, activities offered, level of luxury, and so on. Others, though external to the agent, involve interpretation by the agent to be incorporated in decision-making processes. 
Agents consider these five sets of factors in sequence, narrowing down options in series to reach a final decision. This occurs in an intuitive or tacit process (Brockman \& Antony, 2002), using the agent's knowledge and expertise. Agents narrow down their selection in sequential steps: first profiling the client, and then picking the destination, attraction and operator in series. Destination risks and efficient booking procedures are considered early, to select a region. Location, activities and wildlife are then balanced to select an operator, relying heavily on the agent's own experience. Agents may reconsider each step iteratively in the light of their own knowledge and experience of all the people and places involved. An experienced agent moves rapidly through all these steps to reach a final decision.

Table 1. Factors used in decisions by high-end wildlife travel agents

\begin{tabular}{|c|c|c|}
\hline Category & Factors & Details and Examples \\
\hline Client & $\begin{array}{l}\text { Budget } \\
\text { Requests } \\
\text { Experience } \\
\text { Expectations } \\
\text { Client-agent relationship }\end{array}$ & $\begin{array}{l}\text { Typically set in broad terms at outset } \\
\text { Client preferences for a destination or operator } \\
\text { Previous experience in this subsector } \\
\text { What the client hopes to experience on this trip } \\
\text { Client's previous interactions with agent }\end{array}$ \\
\hline Destination & $\begin{array}{l}\text { Access } \\
\text { Political stability } \\
\text { Health and medical } \\
\text { Seasonality }\end{array}$ & $\begin{array}{l}\text { Distance, time, number of flights, infrastructure } \\
\text { Any safety concerns, recent events, legal issues } \\
\text { Malaria, vaccination requirements, etc } \\
\text { Timing of dry and wet ("green”) seasons }\end{array}$ \\
\hline Attraction & $\begin{array}{l}\text { Lodge or tour location } \\
\text { Scenery } \\
\text { Wildlife viewing } \\
\text { Activities offered } \\
\text { Service quality } \\
\text { Exclusivity } \\
\text { Luxury }\end{array}$ & $\begin{array}{l}\text { Private reserves, concessions in public parks, etc } \\
\text { Spectacular, unmodified scenery ranks highly } \\
\text { Density, diversity, icon species, accessibility } \\
\text { Game drives, game walks, river cruises, etc } \\
\text { Level of service offered at the camps } \\
\text { Exclusivity of the camp, remoteness } \\
\text { Facilities and fittings }\end{array}$ \\
\hline Operator & $\begin{array}{l}\text { Marketing strategies } \\
\text { Sales representative } \\
\text { On-ground inbound agents } \\
\text { Credibility of operator } \\
\text { Reliability of operator } \\
\text { Efficiency of bookings }\end{array}$ & $\begin{array}{l}\text { Brochures, websites, social media, familiarisations } \\
\text { Relationship with the sales representative } \\
\text { Relationship with on-ground inbound agents } \\
\text { Operator reputation and credentials } \\
\text { Agent’s previous experience with operator } \\
\text { Operator booking procedures, efficiency }\end{array}$ \\
\hline Agent & $\begin{array}{l}\text { On-site exposure } \\
\text { Likeability of the operator } \\
\text { Wildlife conservation } \\
\text { Species preference } \\
\text { Educative component } \\
\text { Agency preferred products } \\
\text { Community involvement } \\
\text { Agent's favourite products }\end{array}$ & $\begin{array}{l}\text { Agent's on-site experience of the product } \\
\text { Personal affinities with operator staff } \\
\text { Personal interest in contributing to conservation } \\
\text { Conscious or unconscious bias for some species } \\
\text { Optional activities re conservation or community } \\
\text { Travel agency company list of preferred operators } \\
\text { Agent's interest in operators with local employment } \\
\text { Copying previous choices which worked out well }\end{array}$ \\
\hline
\end{tabular}


In addition to the tangible external factors as above, axial coding of the interview recordings identified overarching internal themes that drive how the agents aggregate and balance all of these many categories of information, most of them incommensurate. We grouped these into four principal themes, which we label as expectations, expertise, experience and empathy.

First, in specialised luxury tourism, high expectations must be met in every part of the supply chain. In their dealings with clients, for example, agents said that "clients' expectations are very high”, "our clients .. have very high expectations”, and “clients pay .. to enjoy a top quality product”. In their dealings with operators, agents said that "we need operators to provide impeccable service”, and "I give only one chance to an operator". Agents expressed these high expectations in terms of risk to their reputation. They referred to "risks associated with the destination" and "risk to start selling [a new] product". They argued that "one negative experience can .. undermine a reputation”, "I can't risk .. my clients' experience”, and "our reputation is at risk if expectations are not met".

Second, the expertise of the specialist travel agents confers both authority and responsibility. All of the agents emphasised repeatedly that they quickly establish their authority to make decisions on the client's behalf, reinforcing their roles as powerful information brokers. They argue that agents must be seen by clients as trustworthy, confident, expert and authoritative: "if you are not credible you will lose your clients". They argue that "the agent knows everything, not the client", "that is why clients seek our expertise", and "clients will listen". Further, they say that "I know what's good for my clients", and "I know what is a good match for them before they even realise it". As a result, they are emphatic that: "I would never let my client choose”, "I assign my own preferences”, “I own the decision-making process", and ultimately, "I have the decision power".

At the same time, all the agents expressed a responsibility to provide their clients with unique, special, and/or unforgettable experiences. They said, for example, that "clients must feel that their holidays are special and tailor-made", and that they aim to "create a special experience”, "organise the perfect safari”, "send clients to special places”, or "let them discover unique places", so as to "provide clients an unforgettable experience" or "an experience they will never forget”. 
Third, agents rely on tacit knowledge gained though practical experience in this specialist subsector and region, and they all felt that experiencing particular tourism products in person is an essential prerequisite to selling them. They referred to "my skills and years in the industry”, "my own knowledge”, "years of experience”, and “expertise from 40 years of experience". They also stated repeatedly that "at this level .. we cannot afford to sell a product that we do not know in person”, "in this market we cannot sell a product that we haven't tested", and "I only sell what I know". As a result, they emphasised that in picking particular products for their clients, "I use my personal knowledge to choose what's best" and "my personal experience plays the most important role". One agent went even further, arguing that personal experience "has 99\% of influence” over their final decisions.

Fourth, empathy allows agents to project themselves into the client's perspective, as a final check that the choices they have made through this multi-step decision process will provide an experience that matches or exceeds the client's expectations. Projection is used unconsciously, and in consequence, agents will often send clients to places they believe the clients will appreciate as much as they do themselves, "places that I fell in love with". Agents say that "the decision is very personal", that they want to "share my passion with my clients", and that ultimately they rely on "my own desires".

\section{Discussion}

The results presented above confirm that in the higher-priced, lower-volume specialist subsectors such as luxury wildlife tourism, travel agents remain a critical intermediary. They use their skills, knowledge and experience to match the high expectations of wealthy and discerning clients with high-quality products from a limited set of specialist luxury tourism operators in sites with the best available wildlife viewing opportunities. As suggested by Buckley (2014), cash-rich, time-poor clients continue to value and rely on the expertise of specialist travel agents, even if this no longer applies to the same degree for cash-poor, timerich tourists. As suggested by Zhang, Leung \& Qu (2007), travel agent decisions follow a sequential process, though the steps are different for wildlife tourism than for the MICE subsector studied in that case. Specialist high-end travel agents use a naturalistic decision making process, which employs tacit knowledge. Agents follow this process competently and successfully, but not consciously. Because of their extensive experience making many such decisions previously, they can use fast rather than slow thinking (Kahnemann, 2011). 
267 The decision process used by these specialist expert travel agents can be expressed in terms of the generalised six-stage consumer decision model of Sirakaya \& Woodside (2005), but the agents themselves do not describe it is those terms. The six stages in that model are: recognition, formulation, alternative generation, information search, judgment or choice, action and feedback. That is a slow-thought, deterministic, explicit and analytical process. The approach followed by specialist travel agents could be dissected in these terms, but the agents use a fast-thought, naturalistic, tacit and intuitive process. This model of travel agent decision is very different from that used in mass-market agencies with short-term sales targets and incentive-based salaries. The model developed here applies only to high-end tourism, where the expertise of individual agents is critical and highly valued, and repeat business relies on their long-term relationships with individual clients, tourism operators, and other intermediaries.

These results reveal the decision process and its drivers in substantially more detail than for any previously available model in the tourism sector. Firstly, the travel agents establish authority over the decision-making process, so that both the tourists and the tour operators rely on the agents to determine the bookings. Secondly, in making these decisions the agents rely largely on personal experience, gained principally though previous familiarisation trips. They only sell what they know, because the risk of losing clients is too great otherwise. Thirdly, they are greatly guided by emotional impressions: products they enjoyed, people they know and trust. Fourthly, one of their key learned skills is the ability to project themselves into their client's place, to imagine a very specific trip from the client's viewpoint. This includes the specific place, operators, attractions, activities and opportunities, time of year, facilities, infrastructure, safety and convenience, level of luxury and service, likely wildlife sightings, community and conservation projects, even the attitudes and background of individual staff.

Two findings merit further research in tourism marketing more generally. The first is the transfer or passage of the decision power from the client to the agent. This is a key step, but it seems that it is not well appreciated by many destination marketing organisations, and even by some individual tour operator sales and marketing teams, who target individual tourists rather than travel agents. The second is that agents use an intuitive, fast-thinking decision process, which relies on personal experience far more than external information. That is, 
booking decisions made by these specialist travel agents are influenced almost entirely by what they have themselves experienced on the ground, and hardly at all by external marketing materials. The former are incorporated automatically into the agents' "fast" thought processes, whereas the latter would first need to be processed and tested, a "slow" thought process that the agents do not undertake.

For operators in the luxury wildlife tourism subsector, these two findings have powerful practical implications. The first is that they should focus their marketing efforts on agents, not clients, since it is the agents who make the decisions on the clients' behalf. The second is that in order to market to these agents, the most effective approach is through personal familiarisation trips, since those direct and emotional personal experiences exert far greater influence in the agent's intuitive decision processes, than any written or numerical information.

\section{References}

Abou-Shouk, M., Lim, W.M., \& Megicks, P. (2013). Internet adoption by travel agents: a case of Egypt. International Journal of Tourism Research, 15, 298-312.

Ajzen, I., \& Driver, B.L. (1992). Application of the theory of planned behaviour to leisure choice. Journal of Leisure Research, 24(3), 207-224.

Baloglu, S., \& Mangaloglu, M. (2001). Tourism destination images of Turkey, Egypt, Greece, and Italy as perceived by US-based tour operators and travel agents. Tourism Management, 22, 1-9.

Bargeman, B., \& van der Poel, H. (2006). The role of routines in the vacation decisionmaking process of Dutch vacationers. Tourism Management, 27, 707-720.

Bernard, H.R. (2000). Social research methods: Qualitative and quantitative approaches. Sage Publications, Inc. Thousand Oaks. 
Berne, C., Garcia-Gonzalez, M., \& Mugica, J. (2012). How ICT shifts the power balance of tourism distribution channels. Tourism Management, 33, 205-214.

Brockmann, E.N., \& Anthony, W.P. (2002). Tacit knowledge and strategic decision making. Group \& Organization Management, 27(4), 436-455.

Buckley, R. (2014). Tour production costs. Journal of Travel Research 53, 418-419.

Buhalis, D., \& Law, R. (2008). Progress in information technology and tourism management: 20 years on and 10 years after the Internet-The state of eTourism research. Tourism Management, 29, 609-23.

Cheong, S.-M., \& Miller, M.L. (2000). Power and tourism: A Foucauldian observation. Annals of Tourism Research, 27, 371-390.

Cheyne, J., Downes, M., \& Legg, S. (2006). Travel agent vs internet: What influences travel consumer choices? Journal of Vacation Marketing, 12(1), 41-57.

Davies, B., \& Downward, P. (2007). Exploring price and non-price decision making in the UK package tour industry: Insights from small-scale travel agents and tour operators. Tourism Management, 28, 1236-1261.

Decrop, A., \& Snelders, D. (2005). A grounded typology of vacation decision-making. Tourism Management, 26, 121-132.

Dolnicar, S., \& Laesser, C. (2007). Travel agency marketing strategy: Insights from Switzerland. Journal of Travel Research, 46, 133-146.

Gore, J., Banks, A., Millward, L., \& Kyriakidou, O. (2006). Naturalistic decision making and organizations: Reviewing pragmatic science. Organization Studies, 27, 925-942.

Gustafson, P. (2012). Managing business travel: Developments and dilemmas in corporate travel management. Tourism Management, 33, 276-284. 
Hsu, T.-K., Tsai, Y.-F., \& Wu, H.-H. (2009). The preference analysis for tourist choice of destination: A case study of Taiwan. Tourism Management, 30, 288-297.

Huang, I.-C., Huang, P.-W., \& Chen, Y.-J. (2004). A study of Taiwan's travel agent salary system: an agency theory perspective. Tourism Management, 25, 483-490.

Hudson, S., Snaith, T., Miller, G.A., \& Hudson, P. (2001). Distribution channels in the travel industry: using mystery shoppers to understand the influence of travel agency recommendations. Journal of Travel Research, 40, 148-154.

Jeng, J., \& Fesenmaier, D.R. (2002). Conceptualizing the travel decision-making hierarchy: A review of recent developments. Tourism Analysis, 7, 15-32.

Kahneman, D. (2011). Thinking, Fast and Slow. New York: Farrar, Strauss, Giroux.

Klenosky, D.B., \& Gitelson, R.E. (1998). Travel agents’ destination recommendations. Annals of Tourism Research, 25, 661-674.

Kracht, J., \& Wang, Y. (2010). Examining the tourism distribution channel: evolution and transformation. International Journal of Contemporary Hospitality Management, 22(5), 736757.

Lam, T., \& Hsu, C.H.C. (2006). Predicting behavioral intention of choosing a travel destination. Tourism Management, 27, 589-599.

Lawton, G., \& Page, S. (1997). Evaluating travel agents' provision of health advice to travellers. Tourism Management, 18, 89-104.

Lawton, L.J., \& Weaver, D.B. (2009). Travel agency threats and opportunities: The perspective of successful owners. International Journal of Hospitality \& Tourism Administration, 10, 68-92.

Lovelock, B. (2008). Ethical travel decisions travel agents and human rights. Annals of Tourism Research, 35, 338-358. 
McKercher, B., Packer, T., Yau, M.K., \& Lam, P. (2003). Travel agents as facilitators or 474.

405

Michie, D.A., \& Sullivan, G.L. (1990). The role(s) of the international travel agent in the travel decision process of client families. Journal of Travel Research, 29, 30-8.

408

Moore, K., Smallman, C., Wilson, J., \& Simmons, D. (2012). Dynamic in-destination

Novak, J., \& Schwabe, G. (2009). Designing for reintermediation in the brick-and-mortar world: Towards the travel agency of the future. Electron Markets, 19, 15-29.

Park, J.-Y., \& Jang, S. (2013). Confused by too many choices? Choice overload in tourism.

Tourism Management, 35, 1-12.

Punch, K.F. (2014). Introduction to social research, quantitative and qualitative approaches.

SAGE Publications Ltd, London.

Riley, R.W., \& Love, L.L. (2000). The state of qualitative tourism research. Annals of

Tourism Research, 27, 164-187.

423

Saaty, T.L. (2008). Decision making with the analytic hierarchy process. International Journal of Services Sciences, 1, 83-98.

Silverman, D. (2010). Qualitative Research ( $3^{\text {rd }}$ edn). London: Sage.

Sirakaya, E., \& Woodside, A.G. (2005). Building and testing theories of decision making by 
435 Song, H., van der Veen, R., Li, G., \& Chen, J.L. (2012). The Hong Kong tourist satisfaction 436 index. Annals of Tourism Research, 39, 459-479.

437

438 Thunholm, P. (2004). Decision-making style: habit, style or both? Personality and Individual 439 Differences, 36, 931-944.

440

441 Zhang, H.Q., Leung, V., \& Qu, H. (2007). A refined model of factors affecting convention 442 participation decision-making. Tourism Management, 28, 1123-1127.

443

444 